Caribbean Routes: Ethnographic Experiences, Theoretical Challenges, and the Production of Knowledge

\title{
Notes on a \\ Rastafari Yard-Space in Urban Ethiopia
}

\author{
Shelene Gomes ' \\ 'Faculty of Social Sciences, The University of the West Indies, \\ St. Augustine Campus, Trinidad and Tobago
}

\begin{abstract}
The significance of the yard or household in social reproduction within the diasporic Caribbean is the focus of this essay. I outline how a Rastafari yard-space is shaped through household production and family formation among diasporic Caribbean peoples within intercultural households and families. This discussion is foregrounded in Rastafari migration or "repatriation" from the Caribbean to the symbolic land grant in Ethiopia. Two intercultural households will be compared: one located in a local Ethiopian neighbourhood in the city of Shashamane and one in the predominantly Rastafari Jamaica Safar or Jamaica neighbourhood of Shashamane. Primarily drawing on my ethnographic observations, this discussion will situate Rastafari positionalities in terms of social, spatial and subjective articulations of inclusion and exclusion, adding to a discussion of the culture concept in the anthropology of the Caribbean.
\end{abstract}

Key words: Caribbean, family, household, place, social reproduction. 


\section{Notas sobre a casa rastafári \\ na Etiópia urbana}

\section{Resumo}

O significado da casa na reprodução social no Caribe diaspórico é o foco deste artigo. Eu exploro como uma casa rastafári é moldado através da produção da casa e da formação da família entre povos diaspóricos caribenhos em um contexto intercultural. Tendo como pano de fundo a migração rastafári ou "repatriação" do Caribe à Etiópia, por meio de uma concessão simbólica de terras, dois grupos domésticos interculturais são comparados: um localizado em um bairro etíope na cidade de Shashamane e outro na vizinhança predominantemente rastafári de Jamaica Safar, ou Bairro Jamaica, na mesma cidade. Baseada sobretudo em observações etnográficas, esta discussão irá situar as posições rastafári em termos de articulações sociais, espaciais e subjetivas de inclusão e exclusão, contribuindo para a importante discussão sobre o conceito de cutlura na antropologia do Caribe. Palavras-chave: Caribe, família, espaço, casa, reprodução social. 


\title{
Notes on a
}

\section{Rastafari Yard-Space in Urban Ethiopia'}

\author{
Shelene Gomes
}

\section{Emplacement and Embodiment}

There is rich scholarship on the socio-spatial and temporal aspects of reproduction and personhood in the anthropology of the Caribbean. In one of these studies of the Afro-Caribbean yard or house and household in the colonial West Indies, Sidney Mintz states, "to relate the concrete, material character of the house and the yard to the activities which go in and around them" is essential in examining social reproduction (Mintz 1989: 231). ${ }^{2}$ My goal in this essay is to outline the Rastafari yard-space in urban Ethiopia. I emphasise the continued importance of the family and household in social reproduction among diasporic Caribbean peoples. ${ }^{3}$ I concur with a more recent position by Barry Chevannes that in the postcolonial Caribbean, yard or "yaad... is a central reference point of self-identification among African-Caribbeans...as the summary of memory, life and hope" (Chevannes 2001: 129-130). Accordingly, historical, material and ideological contexts matter.

In this ethnographic case of self-identified black, Caribbean Rastafari in the Ethiopian city of Shashamane, the notion of repatriation is central to understanding the development of kinship and social relations between Rastafari and local Ethiopians. For Rastafari, Ethiopia is the spiritual and ancestral homeland to which they have "returned." As such, they call themselves "repatriates" rather than "migrants," an emic description to which I adhere. In this paper I build on descriptions of the yard to intercultural interactions, conflicts over land and space, as well as a gendered division of labour to discuss continuities and changes in the Caribbean yard.

I demonstrate the socio-cultural dynamics that go into identifying one space as "Rasta" and another as "Ethiopian."4 To do this I discuss two households in Shashamane, one of Brother John and Sister Adina in central Shashamane where they live amidst local Ethiopian neighbours, and the second of Brother Matthew and Sister Tirunesh in the predominantly Rastafari Jamaica Safar (Jamaica neighbourhood). ${ }^{5}$ Although located in different parts of Shashamane, these two households were similar in many respects. Both were coded as "intercultural." They consisted of a Rastafari repatriated father, a Christian local Ethiopian mother, and children born and raised in Ethiopia. But one difference, and the one that I concentrate on in this essay, is that one household was a Rastafari "yard" and the other an Ethiopian "beit." As I explain, cultural and material factors shape this differentiation, which involve religion, language, food, family organisation as well as house-building materials, layout, and the garden.

\footnotetext{
Portions of this paper have been presented at the International Conference of Ethiopian Studies and the Caribbean Studies Association conference. I wish to thank the anonymous reviewers and the editors for their comments as well as Jeffrey Hoff for proof reading.

"Yard" is a colloquial term used in the West Indies to refer to a house and its surrounding area, and not only to the outdoor area around the house. During the colonial period the term "tenement yard" referred to overcrowded housing areas for the enslaved population. Later, it referred to poor urban areas where multiple families shared one physical yard in which certain household activities were completed together, such as cooking and sharing a water source. Yard residents behaved as kin. At present, the word also refers to a private yard.

Hereafter I refer to Caribbean peoples as Caribbeans or West Indians.

To emphasise these links, I refer to the Rastafari yard as a yard-space in this particular location.

When I first mention emic terms or words in Amharic, I use italics. Thereafter, they appear in normal text.
} 
The ethnographic data for this essay comes from my fieldwork in Shashamane in 2008-2009, and repeat visits in 2012-2015. I engaged mainly in participant-observation and conducted unstructured and semistructured interviews with repatriates, youth, and local relatives. Staying with a Rastafari family, my household consisted of a repatriated Rastafari father, Fyah, who was in his sixties, and his Ethiopian-born children and grandchildren. Fyah's wife, Bernice, who was in her fifties, resided abroad. Their remaining children lived in other areas of Ethiopia. Both Fyah and Bernice were members of the Twelve Tribes Rastafari organisation. I participated in and observed daily household activities such as cooking, cleaning, and weekly trips to the outdoor food market as well as ritual and community events, inclusive of monthly meetings of the Twelve Tribes and Rastafari celebrations.

Given the significance of the yard in social reproduction, I consider how kinship is lived and practised. In line with the long-standing anthropological interest in kinship, I focus on the materiality and meanings of social reproduction in the spaces and places they occur; what Edward Casey calls "being-in-place" (1996: 15). Without relegating place to a secondary status to space, in which the latter is theorised as an entity that exists a priori, I look at the embodied experiences of household members. ${ }^{6}$

I delineate the physical, symbolic, and affective aspects that go into the making of a yard-space. Family organisation and residence type indicate the reproduction of working-class Caribbean and African-Caribbean patterns in this setting. These forms are observable at the same time with everyday instances of cultural hybridity, such as language. Therefore, temporality is another noteworthy factor in the life course of the house, its inhabitants and environment.

I also highlight the role of identity in reproducing social systems and cultural traits, in this instance between Rastafari 'migrants' and 'local' Ethiopians. I engage with ethnography's long-standing concern with emplacing persons, particularly in local situations of power asymmetries where "stasis and purity" (Clifford 1997:7) have been actively reproduced in emic and etic descriptions. James Clifford's (1997) critique of anthropology's obsession with constructing immobile and sedentary subjects is exemplified in ethnographies of both the geographic and diasporic Caribbean. Considering the history of the modern West Indies in proto-capitalism, transcontinental forced and free movements of labour to the plantation, and twentieth century emigrations from the Caribbean to the Global North, it was more challenging to write such ethnographies about Caribbean cultures. ${ }^{7}$ An analysis of household spaces within a Caribbean culture of migration (Fog Olwig 2007; Forde 2011; Horst 2011; Mintz 1989) can add to the ongoing critical debates over cultural production and representation as well as the distinction between biological and fictive kinship. Huon Wardle notes,

an acknowledged feature of Creole kinship is its open-endedness, its inclusivity, and the ability of those who draw on its idioms to stretch and combine the values it entails (Barrow 1996). But, in practice, values may be, and often are, stretched to their elastic limit: for the individual, kinship is frequently a tense balancing and negotiation of near irreconcilables (Wardle 2002: 497).

I attempt to pay attention to Wardle's caution about "balancing and negotiation" in connecting "modes of relatedness" (Forde 2011: 85) to 'fictive' kin to show the reproduction of this elasticity among diasporic Caribbeans. These kinship behaviours are interrelated with other issues such as income, work, and remittances.

6 As such, I use place and space interchangeably.

7 An example of the counter-analysis to the represented fixity of typical ethnographies of 'native' groups (as if such sedentary groups existed) is Janet Carsten's ethnography with residents of a Malay fishing village, Langkawi. This ethnography demonstrated the inter-connections of physical and social mobility. "Although the community can be seen as modelled on the house," Carsten writes, "it is also true that in many respects relations between houses in the wider neighbourhood contrast with those within them. Instead of a sharing of consumption, resources and labour based on principles of hierarchy, houses in the wider community are involved in directly reciprocal exchanges which are conceived as occurring on an equal basis" (1995: 118). 
Consequently, I highlight how matters of class, status, religion and cultural identity play out regarding household production and family formation. Kinship is a core concept that helps in this respect, although a more detailed discussion of anthropological debates surrounding kinship would be the subject of another paper.

In the following sections I outline the ideological significance of repatriation for Rastafari with the expansion of kinship that come with both support and conflicts as well as the spatio-temporal characteristics of intercultural households through the examples of the yard and the beit.

\section{An Introduction to Kinship in the Jamaica Safar}

To provide some historical background to Rastafari repatriation to Ethiopia, this move was guided by a spiritual impetus rather than a more typical economic one. In Rastafari worldview, Ethiopia is Zion or heaven, and the 'West' - inclusive of the Caribbean — is Babylon or hell. His Imperial Majesty Emperor Haile Selassie I, the last monarch of Ethiopia, is a divine figure in Rastafari religion. Repatriation can be contextualised in formal and popular expressions of Pan-Africanism such as Garveyism and Ethiopianism. From the end of the nineteenth century, African Americans and West Indians in the United States, who were not Rastafari, had visited and lived in Ethiopia. A donation of land in Shashamane to be administered by the Ethiopian World Federation (EWF) from Emperor Haile Selassie I in the 1940s-1950s provided the incentive for further physical repatriation to Ethiopia. It was given as a gesture of appreciation for black international opposition to the Italian occupation of Ethiopia in 1935-1941.

Three periods of organised migration to Shashamane occurred in the 1950s, 1970s, and 1990s. Groups of Rastafari funded by organisations, self-funded Rastafari and non-Rastafari members of the EWF migrated to Shashamane with the intention of settling there. The first period consisted of EWF members. The second influx of settlers were Rastafari sent from the Twelve Tribes of Israel organisation in Jamaica in the 197os. Rastafari from the Theocratic Order of Nyahbinghi, known informally as Nyahbinghi, and the Ethiopia Africa Black International Congress or Bobo Ashanti then arrived for the centenary celebrations of His Majesty's birth in 1992, and remained. During the years when I lived in Ethiopia, Rastafari from Twelve Tribes in several Caribbean countries visited Shashamane. More recently, self-funded repatriates have arrived. Up to 2018, estimates of the Rastafari population in Shashamane have ranged from 250-1000 (Bonacci 2015a; MacLeod 2014; Beyecha 2018; Soroto 2011).

The "land grant," as Rastafari call it, is the symbolic centre of global Rastafari imaginings of black autonomy, freedom and well-being as well as moral and financial networks of support. However, following the coup d'état in 1974 which ousted Haile Selassie I, the Ethiopian state no longer recognises this grant. Despite Rastafari repatriation, they have no collective rights to the land. Virtually no repatriates who arrived in the 1950 and 1970s, or their children, hold title deeds for their houses. However, more recent repatriates have purchased houses in Shashamane. ${ }^{8}$

My yard was located in the Jamaica Safar. The neighbours were diverse, consisting of local Ethiopians and Rastafari. I interacted regularly with Brother Matthew and Sister Tirunesh and two of their three children, as well as Brother John, whose business was in the Jamaica Safar, but who resided farther away in ketema (the Amharic word for "town" commonly used by English-speaking residents also). My contact with Sister Adina and their children was limited as her social and kin groups were located in ketema and abroad, particularly in the United States. I met two of Brother John's and Sister Adina's children in their twenties, on different occasions. Between 2012-2015, one of Brother John's children moved to the United States to join a sibling.

8 Portions of this section appear in Gomes (2018). 
This migration from Ethiopia demonstrated the changing composition of the yard and the extension of crossborder networks that are common to both Rastafari and local Ethiopian families.

In general, with marriage and childbearing between Rastafari repatriates of several nationalities and local Ethiopians of various ethnic affiliations, these two households exemplified the intercultural exchange and social reproduction occurring in the neighbourhood. The integration and hybridity of the 'second generation' also was evidenced by many features and institutions. These included language ability and speech patterns, diet and food tastes as well as value systems in terms of marriage and residence patterns. Regarding speech for instance, in my yard the primary language of communication was Jamaican patois. Amharic was used also between Ethiopian-born children and grandchildren. Their interchangeable use of Amharic, patois and English was observable also in Brother Matthew's and Sister Tirunesh's yard. This scenario of language retention and change presents one example of how bodies, spaces and places in these yards are connected to processes of cultural change and continuity.

I now consider how kinship is lived and how Rastafari cultivate these relationships to ensure social reproduction. Janet Carsten's critique of the anthropological distinction between biological and social kinship is relevant to Rastafari use of "Sister" and "Brother" to address persons "in the faith," as Rastafari say or fellow Rastafari,. Recognising that "kinship is constituted out of everyday small acts and events in time" (Carsten 2000: 698), anthropologists have turned to "modes of relatedness" or "cultures of relatedness" to understand how persons constitute multiple relationships socio-spatially over the life course. Maarit Forde (2011) notes that while the nuclear family form was instituted in the colonial Caribbean as an ideal, a large number of mostly working-class Caribbean people live in "extended family households that do not necessarily consist of biological relatives" (Forde 2011: 82). The demarcations of "fictive or artificial kinship to distinguish between biological and imagined or pretended kin relations" (Forde 2011: 85) do not adequately capture the expectations and behaviours of persons across such households.

Such "socially recognized forms of kinship" (Forde 2011: 88) are evident in religious communities and "ritual families." In Forde's study, these function among Spiritual Baptists, Orisha and Revival Zion in Trinidad and Tobago, Jamaica, St. Vincent, Grenada and New York in the United States. I suggest that such relationships function for Rastafari in Shashamane as well. As Forde summarises, "analytically distinguishing between these relationships and other types of kin relations may not reflect actual lived practices" (2011: 86). For instance, many repatriates in Shashamane have lost contact with their biological relatives in countries of origin and transit. Instead, repatriates communicate regularly with Rastafari in Shashamane, other locations in Ethiopia and in the Global North. As noted previously, the visitors to Rastafari households were themselves also Rastafari, who were not biologically related to repatriates.

For the second generation born in Ethiopia, Rastafari religious communities and transnational networks also are significant, as well as their parents. These youth regularly communicate through social media and mobile phones with Rastafari of the same age range in the Global North, rather than with their relatives in the Caribbean and the diaspora. Many have a vague knowledge of these relatives. At the same time, youth are curious to learn about relatives or 'half-siblings' abroad, in line with "the positive value of 'knowing where you've come from"' (Carsten 2000: 689). This sentiment is attributed not only to the lineage of Ethiopian divinity as embodied in Emperor Haile Selassie I and to understanding Rastafari and Ethiopian histories, but also to 'blood' related families.

Biological ties are significant for Ethiopian-born children, but more specifically between parents and children than with 'extended' relatives such as parents' siblings and cousins. This significance can be seen in parents' financial, moral, and physical labours, which are indispensable for children's well-being and the care of grandchildren. For example, Rastafari parents care for grandchildren as well as financially support 
their children. Additionally, typical Caribbean expectations of children caring for elderly parents operate in terms of the reciprocity of care. The expectation is that parents cared for and raised the children, who must then do the same for elderly parents.

Rastafari in Shashamane and abroad function as kin with obligations and expectations of support, just as in Shashamane within Rastafari and local Ethiopian-Rastafari households. The point here is that relationships among Rastafari transnationally and locally as well as 'blood' relatives function together to ensure the reproduction of the Rastafari community in Shashamane.

In the next sections, through micro-level attention to the household, I develop the spatial and temporal issues connected to social reproduction.

\section{A Rastafari Yard and an Ethiopian Beit}

There are several types of household composition and a well-established pattern of relationships that is reproduced between repatriated men and local Ethiopian women; the latter is detailed in other work (Bonacci 2015a). For example, Rastafari repatriates co-habit with spouses and/or children or reside alone. Both consanguineous and affinal households can be found in Shashamane. Rastafari there do not make this distinction or differentiate between blood relatives, relatives by marriage or 'fictive' kin. This is one point that emphasises how modes of relatedness among Rastafari in Ethiopia and in the diaspora are lived.

The reproduction of Caribbean-derived traits is also seen when Ethiopian-born youth of Rastafari parents have children, and in their residence and marriage patterns. When repatriates' children have their own children, especially when daughters have children, they usually reside in their parents' house with young children as this facilitates child care. While this is common among Ethiopian-born children, they also engage in varied residence practices including legal marriage with co-residence, "visiting" while living in separate residences (which can include co-parenting) and co-residence without legal marriage. ${ }^{9}$ In the life-course and inter-generationally, household composition changes to suit the material and emotional needs of persons and families. For example, Tirunesh's and Matthew's son was in a visiting relationship and co-parented with his girlfriend who lived separately in her family's home. None of John's and Adina's children who lived in Shashamane were married or co-residing with their partners. In another example of an intercultural household consisting of a repatriated father and Ethiopian mother in the Jamaica Safar, the son's local Ethiopian wife lived with him, in his family's home.

Carsten writes with reference to stories from adopted children who are now adults,

Here birth does not imply 'diffuse, enduring solidarity', in Schneider's (1980) terms, emptied as it is of the connection to certainty, longevity, or obligations and rights. Meanwhile, from the point of view of the child adoptive kinship is stripped of the elements of choice or preference which anthropologists generally attribute to friendship or 'fictive kinship'. In trying to establish new relations with birth kin, adopted people must somehow reorder the symbols of kinship. The ways in which they do so do not suggest the heavy reliance on a genetic content of kinship which we might expect. A concern about physical attributes plays a part in motivating searches, but apparently loses significance once reunions have occurred (Carsten 2000: 693).

The yard of Brother Matthew and Sister Tirunesh demonstrates the blurriness of these kinship categories. Their networks include Sister Tirunesh's local 'blood' relatives, fellow Rastafari abroad, Rastafari repatriated 'affines' (son's girlfriend's parents) through their grandchildren as well as other repatriates who live in Shashamane.

$9 \quad$ Visiting suggests an ongoing relationship. These are typologies derived from studies of Caribbean marriage and kinship (Smith 1962; Henriques 1949; Clarke 1966). 
Brother Matthew, from Jamaica, and Sister Tirunesh, an internal migrant to Shashamane, have raised their three children together over the past twenty-five years. Initially residing in other rented houses in the same Jamaica Safar, they own the current house. ${ }^{10}$ Their children are now teenagers and young adults in their twenties and thirties with their own children out of visiting and childbearing relationships ${ }^{11}$ - children who claim themselves as Rastafari, like Brother Matthew. Tirunesh was raised in the Orthodox faith and the children have been baptised in the Orthodox Church in Shashamane. While calling themselves Rastafari, the children also identify as both Jamaican and Ethiopian, in contrast to the children of Brother John and Sister Adina who do not identify as Rastafari but primarily as Ethiopian, which I shortly expand on, although these are both intercultural households.

Tirunesh's and Matthew's yard is a spacious one, bordered by a metal fence and concrete blocks, which contains the house and the garden. The type of fencing or boundary, how residents maintain the land surrounding the house, the size of the outdoor yard, the type of flora, the crops in the kitchen garden ${ }^{12}$ all matter in whether the house and its inhabitants are coded as 'Rasta' or 'Ethiopian. ${ }^{{ }^{13}}$ These features contribute to the image of a typical Rastafari yard, and the social perception of the yard. In particular, the material used to build the house, its size, and its facilities (including indoor plumbing), are major indicators of a household's finances. This house itself is made of concrete (or of chika or mud that may be overlaid with concrete) with designated rooms such as an indoor kitchen, front room with a television for leisure, separate bedrooms and an indoor toilet and bath. There is a similar layout in Brother John's yard, with the addition of an outdoor kitchen.

Considering productive labour as it links to social reproduction is useful. Earning a living in Ethiopia's wage economy often means doing precarious work in formal and informal sectors, but especially in the informal sector. For Rastafari in Shashamane, this chronic uncertainty is experienced by both repatriate women and men. Many households generate income through diverse modes, with the additional contribution of monetary remittances from Rastafari abroad. Work entails self-employment in restaurants, catering and cooking food for sale, wine-making, transportation, sale of ready-made clothing and visitor accommodation through room rentals in repatriate homes. These are the most common types of work. Matthew and Tirunesh, for example, have a licensed small business, rooms to let, ${ }^{14}$ and receive remittances. John and Adina similarly have a registered food business. The size, facilities and furnishings in both houses indicate the relative wealth of these families.

The local perception of Rastafari wealth, and Rastafari projection of this façade through items like clothing, shoes and electronics, as compared to perceptions and experiences of local Ethiopian poverty, shapes the image of a Rastafari yard. The Rastafari house, for instance, is envisaged and expected to be made of concrete as opposed to the more common chika house or if the latter material is used, at least a sizeable chika house with identifiable rooms. Demarcated for the purposes of eating (kitchen), socialising (sitting room), sleeping (bedroom) and hygiene (indoor or outdoor latrine), the house is also expected to be located on a large plot of fenced off land with a concrete wall, instead of the usual thin wooden posts weaved together with a latticed wood outer layer. In reality though, these features are observable only in a few Rastafari houses, such as that of Matthew and Tirunesh.

\footnotetext{
10 More accurately, Tirunesh owns the house with the title deed in her name as she is an Ethiopian citizen unlike Matthew. According to Rastafari, in 2017-2018 the Ethiopian government began issuing local identification cards for first, second, and third generation Rastafari who had valid passports. This document comes with the benefits of Ethiopian residence that in principle will make Rastafari eligible for house ownership and small business loans.

11 Childbearing does not necessarily entail a sustained romantic and/or sexual relationship, but the father does recognise paternity and his role, and that of his relatives, in providing for the child.

12 A term commonly used for food that is grown to be eaten in the household, such as vegetables and spices, as compared to non-edible plants.

13 Whether there are workers to cut the grass, plant flowers and vegetables, and tend to it are other considerations.

14 Shashamane has a small local tourist sector, catering to both Rastafari and non-Rastafari visitors from the West.
} 
The fruit trees planted in Tirunesh's and Matthew's yard, of mango and sorrel (hibiscus), are common to the Caribbean landscape, which are replanted in Shashamane. Other crops grown at the yard include potato and peas. Since these also grow well in this region of Ethiopia, they serve as visible connections to the Caribbean and to repatriates' childhood homes in the Caribbean. In my yard, for instance, Fyah asked Rastafari for seeds of a particular breed of mango that had grown around his home in Kingston, Jamaica. These were brought by a Rastafari visitor to Shashamane from Jamaica, supporting Barry Chevannes' point that the yard serves as "metaphor for home" (2001: 129). In planting seeds from his childhood home, Fyah reproduces a sense of his childhood in Jamaica, for his children and grandchildren as well, who themselves have never physically visited Jamaica.

Tim Ingold's emphasis on the inter-connection of nature and society is encapsulated in landscape, where nature is of course socially constructed, and culture also adaptive to the environment. Through his theorisation of taskscape as an "array of activities that weave in and out of one another, variably in harmony and in discord" (Ingold 2000: 17), thinking of body and landscape also meant recognising these "as essentially temporal phenomena" (Ingold 2000: 23) that people inhabit or in which we dwell. In re-conceptualising temporality, Ingold presented a perspective from those who "dwell" in the landscape, both unconsciously and consciously.

As situated within landscapes, houses, then, "have dynamic, processual characteristics encapsulated in the word dwelling" (Carsten and Hugh-Jones 1995: 1). "Houses are frequently thought of as bodies, sharing with them a common anatomy and a common life history" (Carsten and Hugh-Jones 1995:3). The size and facilities in Matthew's and Tirunesh's house have changed with the composition and needs of household members. They have built a well-equipped indoor kitchen, sufficient bedrooms for the children (where grandchildren may sleep also), there is electricity throughout and indoor plumbing for new washrooms. More recently, ensuite bedrooms for visitor accommodation have been constructed adjacent to the main house.

The symbolism of the yard as a tangible, inhabited space in the Zion of Ethiopia underscores its meaning for Rastafari who demonstrate their Rastafari affiliation through other symbols. At the yard of Tirunesh and Matthew, the well-known colours of red, gold and green and images of the Lion of Judah also demarcate this space as Rasta. For instance, a painting of the Lion of Judah figures prominently on a zinc gate or a fence or, in a more understated manner, the outline of the African continent is incorporated into ironwork on house windows. These features depend on residents' personal tastes as well as artistic proclivity and training. Other practises and habits such as language and diet are significant in the identification of households and their residents. The dominant language at Brother Matthew's and Sister Tirunesh's yard is Jamaican patois, and all members of the household, including Sister Tirunesh who learnt it over time, usually communicate in this medium. The children speak both Amharic and patois fluently.

To describe other behaviours and labours at the yard, Sister Tirunesh usually takes on the cooking responsibilities, with Brother Matthew cooking occasionally. In the past, however, Matthew cooked more often, teaching Tirunesh to prepare Caribbean foods. The diet is usually a mixture of popular Ethiopian and Caribbean meals, and those particular to Sister Tirunesh's ethnic group. These meals include rice and peas, stewed beef or ox tail. As a related point, food reflects socio-cultural identity through everyday behaviours. Cooking and eating in the household of Tirunesh and Matthew for example, reinforces a cultural identity as Rastafari for household members, and in particular reflects Matthew's Jamaican tastes cultivated during childhood and adulthood in Kingston. Cooking also signals Sister Tirunesh's incorporation into the Rastafari community. Through food, Rastafari also assert cultural difference to multi-ethnic local Ethiopians, reinforcing the contrastive aspect of ethnic and cultural identity (Barth 1998). 
Turning to the house of John and Adina, it is close to the childhood home of Sister Adina surrounded by mainly local Ethiopian neighbours, as noted. John and Adina raised their four children there, two of whom still reside in the spacious house in proximity to Adina's extended family. Sister Adina's family is well-established in Shashamane. With a house that is divided into well-designated rooms, the organisation of space and the size of the house indicate the family's higher class and social status.

An outdoor kitchen signifies the cooking style more common in local Ethiopian homes. In contrast to the yard of Tirunesh and Matthew, diet in Brother John's home usually adhered to local Ethiopian meals of the staple injera with beef or vegetarian wat (sauce) and rarely popular Caribbean meals, according to Brother John's two children, although their father does know how to cook these foods. Regarding language, Amharic predominates in everyday communication and the children speak negligible patois with a working knowledge of English acquired at school. One of their daughters gave an example of childhood interaction that underscores the use of language in the home. When her father, Brother John, spoke to her in Jamaican patois growing up she understood enough to reply, but to reply in Amharic, and was unable to reciprocate in patois: "When my father talked to me in patois I answer [sic] in Amharic." Although these children know the members of other local Ethiopian-Rastafari households, they have relationships of greater familiarity, intimacy and trust with their mother's family than with any "Jamaican family," as their daughter explained. While Brother John's children self-identify as "Ethiopian," their last name, which is Brother John's Anglo first name identifies them as faranj or "foreign." 15

The household and the socio-spatial environment, as indicated by these factors, shape how John's and Adina's children see themselves as well as their status. As Karen Fog Olwig (2007) notes:

...from the point of view of the logic of social fields, family and kinship as well as places - regarded as the bedrock of social life - therefore do not exist in and of themselves. Rather, they become defined and attain meaning as individuals' lives take social form and place within specific networks of social relations (:12).

In Shashamane, then, Ethiopian-born children in Rastafari-local Ethiopian households self-identify as Rastafari and/or as Ethiopian, depending on socialisation as well as individual sentiments and worldviews. The visible marking of space and social reproduction shape ideas and perceptions. One house is a yard and one is a beit. Fog Olwig's position on social fields complements Heather Horst's point that "home is not just a place, but becomes a site for imagining several key relationships" in the lives of occupants (2011: 30). Bourdieu's discussion of the Kabyle house (1970) shows that the symbolic ordering of space becomes intertwined with habitus or, in a simplified meaning, the systemic reproduction of structure, merging spatial and temporal concerns.

As such, the activities and roles of household members over time are crucial to understanding social reproduction. The function of the household cross-culturally in reproduction is evident not only in biological reproduction and as a source of labour for production, but in the sexual division of labour, and value systems around the gendering of place and role differentiation (Boserup 1970; Barriteau 2001; Mies 1982). A Caribbean gendered division of space is observable in Shashamane in both Rastafari and Rastafari-local Ethiopian households whereby the yard or house tends to be a female sphere and the road a male one. Although the yard serves as both private and public on different occasions, it is generally considered a site of domesticity and thus private. It is associated with women's reproductive labour and activities which are devalued economically and socially in the market economy (Mintz 1989; Barrow 1996).

15 Naming practises in Ethiopia mean that the father's first name is adopted as the child's surname. 
This gendered spatial distinction is generally observable in urban Ethiopia as well, given the cross-societal institutionalisation of patriarchy. The gendered dimension to waged labour in working class urban Ethiopian households sees women and men responsible for earning in the formal and informal economies (Gomes 2017; DeRegt 2010). Based on Konjit Kifetew's country survey conducted at the beginning of the twentieth century regarding gender roles, expectations and attitudes to work in urban and rural locales, "Ethiopian males prefer women who are income-generating. Rural women are expected to help their husbands in farming, animal husbandry, etc. Urban men suggest that their wives should get as much employment as possible in order to support their families" (2006: 127). Most urban and rural Ethiopians in Kifetew's sample indicated that men should take on the breadwinner role in families, demonstrating a shared ideal between the Caribbean and Ethiopian patriarchal societies, although a sizeable percentage said that both husbands and wives should be "considered as breadwinners" (2006: 127): "About $46 \%$ of the respondents said the husband should be the main breadwinner, and only $11 \%$ thought it should be the wife. But $34 \%$ stated that both the husband and the wife should be considered as breadwinners, and 3.9\% put such a responsibility on children, too" (Kifetew 2006: 127).

These ideals may be shared cross-culturally, but they do not reflect the actual experiences of many people of modest income, as Kifetew's data shows. This is why class is a significant factor in understanding the interplay of ideal behaviours and lived experiences, particularly within social structures and market economies that are based on this gendered division of labour. There is a history of women's productive labour in the colonial and postcolonial Caribbean as well (for examples see Katzin 1959; Mintz 1989; Freeman 2000; Mohammed 2002; Ho 1993) and also in diasporic Caribbean households in Shashamane. While the gendered distinction between productive and reproductive work persists in both Rastafari, and in Rastafari-local Ethiopian households, women do engage in more regular waged labour outside the yard than men, taking on the breadwinner role that is associated with a patriarchal-derived ideal of masculinity. These socio-economic structures, combined with the need to earn money in situations where men's work does not provide sufficient family or household income, mean that women's labour is persistently undervalued. Therefore, women earn less than men's already low wages, and have less income to contribute to families, although this is necessary income (Barriteau 2001; Ho 1993). There appears to be a significant similarity in gender roles and the gendered division of labour at the household level between Rastafari and local Ethiopians, which warrants further research in multi-ethnic urban Ethiopia.

Factoring in class is critical since productive and reproductive work overlap in poor households. However, in Sister Adina's and Sister Tirunesh's households, sufficient income proscribes their need to earn. Instead, both women focus on domestic, reproductive and care work. Their networks of social relations, particularly with Rastafari 'kin' globally, through their husbands, and with children and relatives in the United States mainly for Adina and John, provide financial support. In both households, although small crops are grown, livelihood activities in the waged economy predominate, and is supplemented by remittances from Rastafari abroad, also demonstrating the transnational dimension to earning a living. I turn now to the broader interconnections of community and yard.

\section{Being Rooted: Locating Identities in Time and Space}

In building up an image of the yard-space, issues of identity and symbolic-material linkages feature significantly. The socio-cultural changes and continuities previously described link to Clifford's critique of the rootedness of culture and therefore identity in anthropology. As an identity category and as an everyday expression of belonging, the fluid embodiment of Rastafari, Ethiopian, Jamaican and faranj are imbued with ideas of entitlement, which most clearly emerge in conflicts over the land. From my observations, when local Ethiopians of various ethnicities say "Jamaican" or "Rasta" in everyday conversation, it is culturally juxtaposed 
with "Ethiopian" and coded as faranj. Among local Ethiopians too, "Ethiopian" is juxtaposed to a hegemonic Ethiopian identity as "Habesha," an Amharic term referring to an Abyssinian-derived, northern Ethiopian social and ethnic identity that positions other ethnicities as inferior (Jalata 2009).

From a local Ethiopian perspective, Rastafari are not only faranj but also territorially 'uprooted' from their homes in the Caribbean - unable to prove Ethiopian ancestry. Consequently, claims to land, especially land that was historically granted by a deposed Ethiopian emperor, are null. If 'culture' is equated with fixity then 'uprooted' people are seen as having lost culture: "violated, broken roots signal an ailing cultural identity and a damaged nationality" (Malkki 1995: 15). Within Rastafari worldview, however, Rastafari are historically tied to Ethiopia, and this specific space in Shashamane. Rastafari also actively create home through the yard and its kin networks, thereby 'rooting' themselves within present day Ethiopia.

Despite the dispossession, the land grant symbolises dignity, recognition of black and Ethiopian identities and equality for Rastafari globally. This Rastafari historical claim to the land is kept alive by first and second generations in Ethiopia, in everyday interaction at home and at ritual events, and for Rastafari abroad through rites, inclusive of visiting Shashamane and contributing to community, household, and individual survival through remittances. In this moral landscape, the tension between Rastafari and local Ethiopians around the land is noticeable in stories, remarks and anecdotes that circulate in Shashamane. As Giulia Bonacci (2015b) notes, two of the terms given to early (at that time non-Rastafari) Ethiopian World Federation settlers, "sädätäñña färänjoch" and "balabbat," which mean foreigners and landowners, provide insight into local attitudes, state classifications of repatriates, and social inequality. Used in written sources in 1959, Bonacci argues that the term sädätäñña färänjoch characterised repatriates as "different" from locals and hence faranj, but also different from white European faranjoch (the plural of faranj) who lived in Ethiopia

They were not white but some of their everyday practices were seen as such - or simply as different. They talked English, drove a car, were sometimes dressed in suit, tie and hat, cooked standing, and ate with knives and forks. The term sēdätäñña expresses agency and means refugee, immigrant or emigrant... The expression sēdätäñña färänj is as uncommon as were the Caribbean settlers. This name identified them as coming from elsewhere like the färänjočč, but they were also perceived as migrants and refugees in Ethiopia where they were planting new roots (Bonacci 2015b: 40-41).

This excerpt demonstrates that the present-day attitude toward black Rastafari as faranj was nuanced in the past. When the first repatriates arrived, local Ethiopians recognised their difference from preceding white and European settlers. However, the 'migrants' had a privileged position as recipients of land. In the imperial period, gult land tenure practises meant that landowners and labourers were of different strata. In Shashamane, these initial settlers took on the role of landowners or balabbat. In imperial Ethiopia, following the conquest of independent southern territories and incorporation into the Empire, balabbat were usually "chosen from among the local population; they were granted land and administrative responsibility by the Ethiopian central power (Mantel-Niecko 1980, 69). It is only because they were beneficiaries of imperial politics over southern lands that the Caribbean settlers were named balabbat by their neighbors" (Bonacci 2015b: 42). Although this term is no longer used in Ethiopia, particularly following the 1974 revolution and subsequent changes in governance and land tenure, these historical terms indicated the variable status of early non-Rastafari repatriates.

The changing local perceptions of non-Rastafari settlers and Rastafari repatriates around access to and ownership of land manifest in a widely-circulated story in Shashamane, and noted by Erin MacLeod according to which the imperial state granted Rastafari land to spy on Oromo residents either as "punishment" or a form of intimidation (2014: 101). These negative rumours and stories circulate within the Jamaica Safar while at the same time repatriated Rastafari and multi-ethnic locals interact daily. Whether buying food in the local 
ketema market, subjected to increasing prices, through intermarriage and childbearing, attending school, or participating in community savings schemes, there is constant communication, support as well as conflict in institutional and everyday spheres among these 'locals' and 'migrants.'

Although many Rastafari have settled in a particular area of Shashamane, hence the name that has spontaneously arisen of "Jamaica Safar," multi-ethnic Ethiopians and Rastafari of several nationalities live side by side, as mentioned. However, MacLeod (2014) suggests that changing perceptions of social space, and of claims and entitlements to land in Shashamane between local Ethiopians and Rastafari, can be interrogated in terms of Henri Lefebvre's theory of space as lived and perceived. In twenty-first century Shashamane, local political projects for the development of the city emphasise,

The practical, economical, financial, and developmental side - the perceived space... However, a different maneuver is undertaken by Rastafari. They look outside the time and space of contemporary Shashemene to make an argument...by referencing the granted land by the imperial government and the negotiated maintenance of this land through an agreement with the Dergue [following the 1974 revolution], they [Rastafari] are using what could be called old maps to locate their space (MacLeod 2014: 111-112).

This creates dissensus in how the space is lived between Rastafari and local Ethiopian residents. Although acknowledging the inter-relation between ideological underpinnings and the use of public space in social interaction in Shashamane, MacLeod's relegation of "old maps" to assess Rastafari imaginative self- and placemaking is limited. Rather, as Miriam Kahn writes, "places are complex constructions of social histories, personal and interpersonal experiences, and selective memory" (Kahn 1996: 167). This applies to the wider spaces of the Jamaica Safar, ketema as well as the household.

To end, the impacts of diverse and diverging conceptions of place are observable in the changing status of Rastafari and initial repatriates as foreigners, landowners, refugees and Ethiopians, with the development of kin relations as well as in conflicts with kin and neighbours. These behaviours indicate that issues of social reproduction, kinship and cultural change are also pertinent.

In this discussion of the making of a Rastafari yard in Shashamane, I have attempted to highlight how Rastafari emplace themselves on an everyday basis, and how the social identities of Rastafari or Ethiopian are useful inter-connected strands to consider. I have outlined the features of a yard-space following the migration or repatriation of Rastafari from the Caribbean to Ethiopia for spiritual and moral reasons. This Rastafari settlement on the historic land grant has led to the establishment of intercultural households in the multicultural Jamaica Safar. With examples from two intercultural Rastafari-local Ethiopian households, these notes have highlighted the factors deployed in categorising a yard versus a beit, even while recognising the similarities between these households, such as a sexual division of labour. One factor is the location of the yard and the shaping of the space, with others inclusive of language, religion, diet and family organisation. The inter-changeable use of Amharic, patois and English in Brother Matthew's and Sister Tirunesh's yard, for example, took a different form in Brother John's and Sister Adina's household. Diet and cooking in each home also differed and are noteworthy features in delineating individual and social identities. In short, these two households showed processes of intercultural exchange and social reproduction taking place in the wider neighbourhood.

The symbolism of the land grant for Rastafari globally and cultural-material issues that shape the yardspace, resonate with how place is sensed and the house itself is experienced and made by different actors. The house and neighbourhood continue to be important loci of socialisation as well as individual attitudes, thereby extending the discussion of kinship and relatedness to those with whom we live and build relationships, which has been a feature of Caribbean kinship. These behaviours are interrelated with tangible material concerns of 
work, generating income and receiving remittances, which reinforce the transnational dimension to Caribbean cultures. Class, status, religion and cultural identity are integral to understanding household production and family formation. In focussing on diasporic Caribbeans in the Global South, this paper has centred longstanding issues of emplacing peoples and cultures in the anthropology of the Caribbean.

Submitted: September 26, 2019

Approved: March 02, 2020

Revised by: Jeffrey Hoff

\section{Bibliography}

BARRITEAU, V. Eudine. 2001. The Political Economy of Gender in the Twentieth-Century Caribbean. New York: Palgrave.

BARROW, Christine. 1996. Family in the Caribbean: Themes and Perspectives. Kingston and Oxford: Ian Randle and James Currey.

BARTH, Fredrik. 1998. "Introduction”. In F. Barth (ed.), Ethnic Groups and Boundaries: The Social Organization of Culture Difference. Illinois: Waveland Press Inc. pp 9-38.

BEYECHA, Mahlet Ayele, 2018. The Rastafari in Ethiopia: Challenges and Paradoxes of Belonging. Masters Thesis, Leiden University.

BONACCI, Giulia. 2015a. Exodus!: Heirs and Pioneers, Rastafari Return to Ethiopia. Translated and edited by Antoinette Tidjani Alou. Kingston, Jamaica: The University of the West Indies Press. . 2015b. "Mapping the Boundaries of Otherness: Naming Caribbean Settlers in Ethiopia". African Diaspora, 8(1): 34-50. doi: 10.1163/18725465-00801002.

BOSERUP, Ester. 1970. Woman's Role in Economic Development. London: Earthscan.

BOURDIEU, Pierre. 1970. “The Berber House or The World Reversed”. Information (International Social Science Council), 9(2): 151-170.

CARSTEN, Janet. 2000. "Knowing Where You've Come from': Ruptures and Continuities of Time and Kinship in Narratives of Adoption Reunions". The Journal of the Royal Anthropological Institute, 6(4): 687703. doi.org/10.1111/1467-9655.00040.

CARSTEN, Janet. 1995. "Houses in Langkawi: Stable Structures or Mobile Houses"? In J. Carsten and S. Hugh-Jones (eds.), About the House: Lévi-Strauss and Beyond. Cambridge: Cambridge University Press. pp.105-128.

CARSTEN, Janet and HUGH-JONES, Stephen (Eds.). 1995. About the House: Lévi-Strauss and Beyond. Cambridge: Cambridge University Press. pp.1-46.

CASEY, Edward. 1996. "How to Get from Space to Place in a Fairly Short Stretch of Time: Phenomenological Prolegomena". In: S. Feld and K. H. Basso (eds.), Senses of Place. Santa Fe, New Mexico: School of American Research. pp.13-52.

CHEVANNES, Barry. 2001. "Jamaican Diasporic Identity: The Metaphor of Yaad”. In: P. Taylor (ed.), Nation Dance: Religion, Identity, and Cultural Difference in the Caribbean. Bloomington: Indiana University Press. pp.129-137. 
CLARKE, Edith. 1966. My Mother who Fathered Me: A Study of the Family in Three Selected Communities in Jamaica. London: George Allen and Unwin.

CLIFFORD, James. 1997. Routes: Travel and Translation in the Late Twentieth Century. Cambridge, MA: Harvard University Press.

DEREGT, Marina. 2010. "Ways to Come, Ways to Leave: Gender, Mobility, and II/Legality among Ethiopian Domestic Workers in Yemen". Gender and Society, 24(2): 237-26o. doi:10.1177/ 0891243209360358.

FOG OLWIG, Karen. 2007. Caribbean Journeys: An Ethnography of Migration and Home in Three Family Networks. London: Duke University Press.

FORDE, Maarit. 2011. "Modes of Transnational Relatedness: Caribbean Migrants' Networks of Child Care and Ritual Kinship". In: C. Coe et al (eds.), Everyday Ruptures: Children, Youth, and Migration in Global Perspective. Nashville: Vanderbilt University Press. pp.79-96.

FREEMAN, Carla. 2000. High Tech and High Heels in the Global Economy. Durham: Duke University Press. GOMES, Shelene. 2018. "Counter-Narratives of Belonging: Rastafari in the Promised Land". The Global South, 12(1): 112-128. doi: 10.2979/globalsouth.12.1.07.

GOMES, Shelene. 2017. "Meseret's Story: Women, Work and Betterment in an Ethiopia-Saudi Arabia Return Labor Migration”. African and Black Diaspora: An International Journal, 11(1): 51-68. doi: 10.1080/17528631.201 7.1342981.

HENRIQUES, Fernando. 1949. "West Indian Family Organization". American Journal of Sociology, 55(1): 30-37. HO, Christine. G. T. 1993. "The Internationalization of Kinship and the Feminization of Caribbean Migration: The Case of Afro-Trinidadian Immigrants in Los Angeles". Human Organization, 52(1): 32-40. doi.org/10.1773o/humo.52.1.h424j806mo23r464.

HORST, Heather. 2011. "Reclaiming Place: The Architecture of Home, Family and Migration”. Acta Anthropologica, 53(1): 29-39.

INGOLD, Tim. 200o. The Perception of the Environment: Essays on Livelihood, Dwelling and Skill. London: Routledge.

JALATA, Asafa. 2009. "Being In and Out of Africa: the Impact of Duality of Ethiopianism.” Journal of Black Studies, 40 (2): 189-214. doi: 10.1177/0021934707307833.

KAHN, Miriam. 1996. "Your Place and Mine: Sharing Emotional Landscapes in Wamira, Papua New Guinea”. In: Steven Feld and Keith H. Basso (eds.), Senses of Place. Santa Fe, New Mexico: School of American Research. pp.167-196.

KATZIN, Margaret. F. 1959. “The Jamaican Country Higgler”. Social and Economic Studies, 8(4): 421-435.

KIFETEW, Konjit. 2006. "Gender and Cross Cultural Dynamics in Ethiopia”. Agenda: Empowering Women for Gender Equity, 68: 122-127.

MACLEOD, Erin. 2014. Visions of Zion: Ethiopians and Rastafari in the Search for the Promised Land. New York and London: New York University Press.

MALKKI, Liisa. 1995. Purity and Exile: Violence, Memory, and National Cosmology Among Hutu Refugees in Tanzania. Chicago: University of Chicago Press.

MANTEL-NIECKO, Joanna. 1980. The Role of Land Tenure in the System of Ethiopian Imperial Government in Modern Times. Translated by K. A. Bobinski. Warsaw: Wydawnictwa Uniwersytetu Warszawskiego.

MIES, Maria. 1982. The Lace Makers of Narsapur: Indian Housewives Produce for the World Market. London: Zed Press.

MINTZ, Sidney, W. 1989. Caribbean Transformations. New York: Columbia University Press Morningside Edition.

MOHAMMED, Patricia. 2002. Gender Negotiations among Indians in Trinidad 1917-1947. Houndmills, Basingstoke: Palgrave Macmillan. 
SMITH, Michael. G. 1962. West Indian Family Structure. London: University of Washington Press.

SOROTO, Solomon. 2011. Settlement and Integration of Rastafarians in Shashemene, Ethiopia: An Anthropological Perspective. Germany: VDM Verlag.

WARDLE, Huon. 2002. "A Groundwork for West Indian Cultural Openness". The Journal of the Royal Anthropological Institute, 13(3): 567-583.

Shelene Gomes

Sociology Unit, Department of Behavioural Sciences

Faculty of Social Sciences

The University of the West Indies, St. Augustine.

Trinidad and Tobago

https:|/orcid.org/000o-0002-3499-6278

Email: shelene.gomes@sta.uwi.edu 